\title{
Republican spending plan casts shadow on science
}

Romney's running mate, Paul Ryan, wants to curb expenditure on non-defence research.

\section{BY AMY MAXMEN}

W hen the spotlight falls on Tampa, Florida, next week for the US Republican National Convention, science will not be an obvious part of the agenda. Delegates can expect to hear about the need to cut the federal deficit, reduce spending and limit government - all key positions for the fiscally conservative party and for Mitt Romney, who will be nominated as its presidential candidate at the convention.

The Republicans' economic message is familiar, but some research advocates warn that if Romney wins the general election on 6 November, it could translate into a pronounced shift in the US government's approach to science. They fear the party will reduce the overall budget for research, shift its emphasis, and target regulations it sees as hampering economic growth.

"In general, conservatives believe that society has been over-regulated and that there are areas to be cut back in order to be improved," says Kenneth Green, a fiscally conservative resident scholar at the American Enterprise Institute, a think tank in Washington DC.

Romney's choice of Wisconsin congressman Paul Ryan as his running mate is the latest sign that the party is ready to push for big changes. As chairman of the House of Representatives budget committee in the current Congress, Ryan has crafted a federal spending plan that contrasts sharply with that of President Barack Obama, whose budget requests have largely maintained science and technology funding as an economic investment.

If carried out, Ryan's plan could cut spending on non-defence-related research and development by $5 \%$, or $\$ 3.2$ billion, below the fiscalyear 2012 budget, according to the American Association for the Advancement of Science.

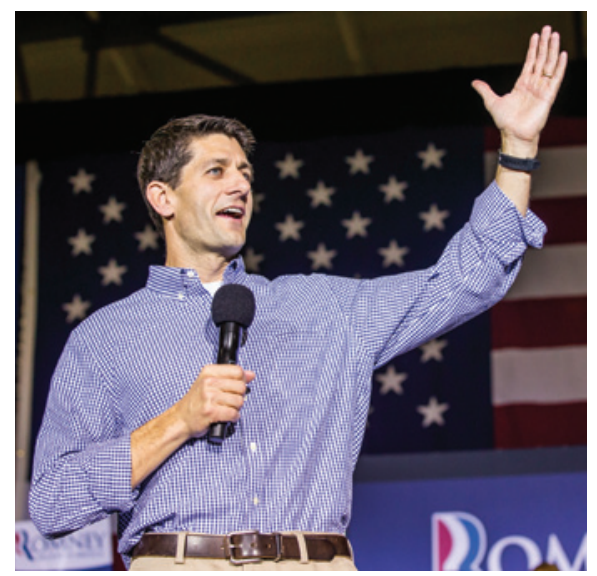

Paul Ryan aims to limit government's reach.

Over the long term, Ryan's small-government approach would shrink funding for research and development to historically small sizes.

Ryan's spending caps would also represent a change in emphasis in the type of science that is supported. Although Ryan's economic plan voices support for "basic research and development", it would pare back spending in applied research and projects "best left to the private sector". Science advocates worry that this might include research such as clinical trials sponsored by the National Institutes of Health for therapies from which the drug industry would be unlikely to profit. Ryan's budget proposals have won the support of the Republican-led House, but they have been blocked by the Senate, where Democrats hold a slim majority.

"We are glad that Congressman Ryan and Governor Romney have acknowledged the importance of funding basic research as a core government function, but we are extremely concerned that Ryan's budget appears to reflect the opposite," says Mary Woolley, president of
Research!America, a science-advocacy group based in Alexandria, Virginia.

"Governor Romney understands that innovation is crucial to our prosperity," a campaign 总 spokeswoman told Nature. She also noted that Romney has emphasized the need to attract and retain people with advanced degrees in science-related disciplines by expanding the availability of visas for skilled immigrants.

In selecting Ryan as his running mate, Romney has shifted his campaign towards those in his party who support limiting the government's reach. For example, even among his Republican colleagues in the House, Ryan stands out in his opposition to environmental regulation. According to the League of Conservation Voters, an environmental-advocacy group based in Washington DC, Ryan was among the 16 of 242 House Republicans who voted against almost all of the environmental actions that the league considered priorities in 2011. In addition to opposing funding for the listing of plants and animals under the Endangered Species Act and Obama's push for the development of alternative-energy technologies, Ryan, through his budget plan, takes aim at the Environmental Protection Agency for its measures to regulate carbon emissions.

Ryan has also taken a hard line on the US Food and Drug Administration (FDA) for example, by voting against a food-safety bill that expands the agency's role in detecting food contaminated by pathogens such as Salmonella. He also voted to exempt tobacco products from the agency's oversight and to repeal legislation appropriating funds for preventive-health programmes.

"If the way to show your cred is by attacking regulation, that's not a good outcome for science agencies," says William Hubbard, a former FDA associate commissioner.

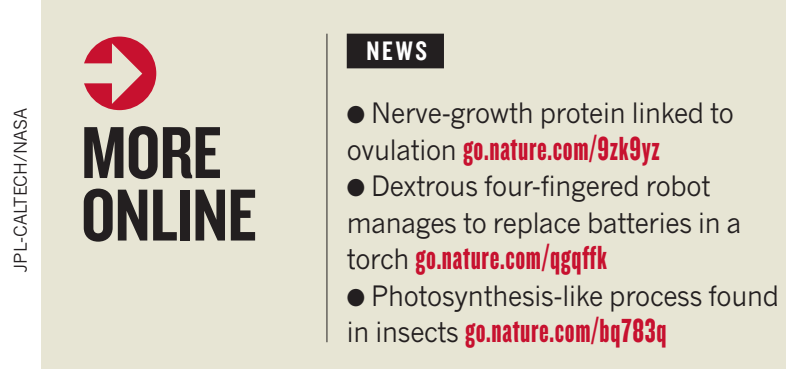

\section{VIDEO}

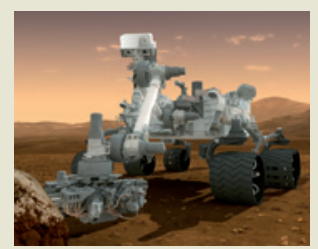

Curiosity rover takes its first look at Mars go.nature. com/qeuxhl

\section{BLOG}

- Blood cells converted into chemical sensors go.nature.com/dxjutj - 'Virus-like' nanoparticle built to target tumours go.nature.com/gzcez2 - D-Wave quantum computer solves protein-folding problem go.nature.com/ ggaajh 